\title{
EKSTRAKSI KOMPONEN BIOAKTIF SERBUK KAYU SECANG (Caesalpinia sappan, L) DENGAN METODE ULTRASONIKASI
}

\author{
Neswati dan Sahadi Didi Ismanto \\ Program Studi Teknologi Hasil Pertanian, Fakultas Teknologi Pertanian, Universitas Andalas \\ E-mail: neswati@gmail.com
}

\begin{abstract}
ABSTRAK
Komponen bioaktif dari kayu secang (Caesalpinia sappan, L) dapat dimanfaatkan sebagai antibakteri dan antioksidan. Komponen bioaktif tersebut dapat diekstraksi dengan menggunakan metode ultrasonikasi yang diberi perlakuan jenis pelarut (air dan etanol), suhu ekstraksi $\left(20^{\circ} \mathrm{C}, 30^{\circ} \mathrm{C}\right.$ dan $40^{\circ} \mathrm{C}$ ) dan lama ekstraksi (20 menit, 30 menit dan 40 menit). Adapun parameter yang diuji yaitu antibakteri Staphylococcus aureus dengan metode zona bening, aktivitas antioksidan IC 50, total fenol, dan total flavanoid. Hasil penelitian menunjukkan bahwa kondisi optimum ektraksi kayu secang dengan metode ultrasonikasi adalah menggunakan pelarut etanol $65 \%$ pada suhu $30^{\circ} \mathrm{C}$ selama 40 menit dengan parameter yaitu kadar flavonoid sebesar $0,0667 \pm 0,0053 \mathrm{mg}$ QE/g sampel, kadar total fenol sebesar 38,7500 $\pm 3,6534 \mathrm{mg}$ GAE/g sampel, antibakteri Staphylococcus aureus sebesar $23,25 \pm 1,2021 \mathrm{~mm}$, dan aktivitas antioksidan $\mathrm{IC}_{50}$ sebesar $1,2978 \pm 0,0013 \mathrm{mg} / \mathrm{mL}$.

Kata kunci-caesalpinia sappan, L.; ekstrasi; komponen bioaktif; ultrasonikasi
\end{abstract}

\section{PENDAHULUAN}

Secang (Caesalpinia sappan, L) adalah tanaman dari keluarga Leguminosae. Umumnya Secang dikenal sebagai Brasil atau kayu secang. Kayu secang didistribusikan di Asia Tenggara dalam bentuk kering yang telah digunakan sebagai bahan tradisional untuk makanan atau minuman (Toegel, Wu, Otero, Goldring, Leelapornpisid, Chiari, 2012).

Nirmal, Rajput, Prasad, Ahmad (2015) menyatakan bahwa kayu secang mengandung flavonoid yang larut dalam air yaitu, brazilin, protosappanin dan hematoksilin. Pigmen brazilin yang berasal dari kayu secang memiliki sifat antioksidan, anti kanker, anti inflamatori, dan anti diabetes. Selain itu pigmen brazilin dari kayu secang dapat berfungsi sebagai antimikroba seperti Staphylococcus aureus.

Brazilin dapat diaplikasikan dalam pembuatan makanan fungsional, sebagai pengawet dan pewarna makanan (Nirmal et al., 2015). Sediaan brazilin dalam bentuk pekat atau kering dapat lebih mudah disimpan dan lebih tahan lama. Sedian brazilin dapat diekstrak dari kayu secang dengan menggunakan berbagai metode ekstraksi. Selama ini cara yang paling banyak digunakan adalah dengan metode maserasi. Berdasarkan hasil penelitian Deng, Xu, Xiang, Liu, Zhao, Li dan Yang (2017) menyatakan bahwa metode ekstraksi dengan ultrasonic bath menghasilkan rendemen ekstrak yang lebih tinggi dengan penggunaan pelarut yang lebih sedikit, waktu ekstraksi yang lebih singkat, suhu ekstraksi yang lebih rendah jika dibandingkan dengan metode ekstraksi maserasi.

Kualitas ekstrak yang diperoleh sangat tergantung pada kondisi optimal selama proses ekstraksi diantaranya jenis pelarut, suhu, dan lama. Pelarut yang sesuai digunakan untuk mengekstraksi barazilin adalah pelarut-pelarut polar, karena menurut Godwin (1976) di dalam Puspaningrum (2003), brazilin bersifat mudah larut dalam air panas dan larut dalam alkohol. Pelarut polar yang digunakan dalam penelitian ini adalah air dan etanol, karena kedua pelarut ini cukup aman digunakan untuk dikonsumsi. Suhu ekstraksi berkorelasi negative dengan lama ekstrasi. Semakin tinggi suhu ekstraksi maka waktu ekstrasi akan semakin singkat.

Chen, Zhang, Liu, Gu dan Yang (2017) menyatakan bahwa kondisi ekstraksi optimum ultrasonic bath untuk memperoleh rendemen orientin dan vitexin yang tinggi dari bunga Trollius chinensis adalah menggunakan pelarut etanol $60 \%$ pada suhu $30^{\circ} \mathrm{C}$ selama 28 menit. Selanjutnya Deng et al (2017) menjelaskan bahwa kondisi ekstraksi optimum dengan bantuan ultrasonic untuk senyawa fenol dari buah zaitun adalah pada suhu $47^{\circ} \mathrm{C}$ selama 30 menit.

Penelitian ini bertujuan untuk menentukan kombinasi antara jenis pelarut, suhu, dan lama ekstraksi yang optimum berdasarkan kandungan komponen bioaktif ekstrak kayu secang (Caesalpinia sappan, L.). 


\section{METODOLOGI PENELITIAN}

\section{A. Bahan dan Alat}

Bahan utama yang digunakan dalam penelitian ini adalah kayu secang. Bahan kimia yang digunakan untuk ekstraksi adalah etanol dan aquades. Bahan kimia yang digunakan untuk analisis ialah indikator kanji/pati (1\%), larutan iod $0,01 \mathrm{~N}$, aquades, methanol, DPPH, larutan aseton.

Alat-alat untuk analisis kimia berupa timbangan analitik, blender, gelas piala $500 \mathrm{ml}$, labu ukur $100 \mathrm{ml}$, gelas ukur $100 \mathrm{ml}$, cawan alumunium, cawan porselen, erlenmeyer, pipet tetes, desikator, oven, ultrasonic bath (Merk Elma, S.30H), stopwatch, tupperware, silika gel, kertas saring, alumunium foil, gelas, kapas, buret, tanur.

\section{B. Rancangan Penelitian}

Penelitian ini dirancang dengan menggunakan 3 Faktor perlakuan dan masing-masing perlakuan terdiri dari 2 ulangan. Perlakuan penelitian ini adalah:

$\mathrm{A}=$ Jenis pelarut $\left(\mathrm{A}_{1}=\right.$ Air dan $\mathrm{A}_{2}=$ Etanol $\left.65 \%\right)$

$\mathrm{B}=$ Suhu Ekstraksi $\left(\mathrm{B}_{1}=20^{\circ} \mathrm{C}, \mathrm{B}_{2}=30^{\circ} \mathrm{C}\right.$, dan $\left.\mathrm{B}_{3}=40^{\circ} \mathrm{C}\right)$

$\mathrm{C}=$ Lama Ekstraksi $\left(\mathrm{C}_{1}=20\right.$ menit, $\mathrm{C}_{2}=30$ menit, dan $\mathrm{C}_{3}=40$ menit $)$

\section{Pelaksanaan Penelitian}

a. Persiapan Bahan Baku

1. Kayu secang dikeringkan dengan oven pada suhu $60^{\circ} \mathrm{C}$ sampai kadar air $10 \%$

2. Kayu secang yang sudah kering diperkecil ukurannya dengan blender dan diayak denagn ayakan 40/60 mesh

b. Proses Ekstraksi ( Modifikasi Deng, et al, 2017)

1. Serbuk kayu secang ditimbang sebanyak $10 \mathrm{gr}$, dan tambahkan pelarut sesuai perlakuan sebanyak $220 \mathrm{ml}$ (ratio bahan dengan pelarut $=1 \mathrm{gr}: 22 \mathrm{ml}$

2. Ekstraksi dengan bantuan ultrasonik pada suhu sesuai perlakuan selama sesuai perlakuan.

3. Suspensi yang diperoleh disaring dengan kertas saring

4. Kemudian dipekatkan dengan rotary vacuum evaporator sampai mencapai kepekatan $30 \mathrm{ml}$

\section{Pengamatan}

Pengamatan yang dilakukan terhadap ekstrak kayu secang yaitu:

1. Uji antibakteri Staphylococcus aureus dengan metode zona bening (Muharni, Fitrya, dan Farida, 2017 dimodifikasi)

Uji aktivitas antibakteri dilakukan dengan metode difusi agar menggunakan kertas cakram (paper disc) berdiameter $6 \mathrm{~mm}$ dengan bakteri Staphylococcus aureus. Uji antibakteri yang menggunakan kertas cakram dilakukan dengan melarutkan 5,00 gram ekstrak kayu secang ke dalam $45 \mathrm{ml}$ aquades dalam gelas piala. Kertas cakram direndam kedalamnya selama satu malam, kemudian cakram ditempelkan pada media blood agar yang telah ditanamkan bakteri. Lalu diinkubasi dalam incubator pada suhu $37^{\circ} \mathrm{C}$ selama $2 \times 24$ jam. Diameter zona inhibisi diukur dengan jangka sorong dan penggaris.

2. Aktivitas antioksidan IC 50 (Singh, Singh, Kapoor, Singh, Isidorov, dan Szczepaniak, 2013 dimodifikasi)

Sebesar $2 \mathrm{~mL}$ sampel dimasukkan ke dalam tabung reaksi, kemudian ditambahkan DPPH $0,002 \%$ sebanyak $2 \mathrm{~mL}$ yang dilarutkan dalam methanol. Selanjutnya sampel dihomogenkan dan diinkubasi selama 30 menit dalam ruang gelap. Absorbansi diukur pada panjang gelombang $517 \mathrm{~nm}$ dengan spektroskopi UV-VIS, dilakukan sebanyak 3 kali ulangan. Sebagai standar digunakan asam askorbat pada konsentrasi 0,$5 ; 1 ; 1,5 ; 2 ; 2,5 \mathrm{ppm}$. Nilai absorbansi yang diperoleh dihitungan dengan rumus:

$\%$ inhibibisi $=\frac{(\text { absorbansi blanko }- \text { absorbansi sampel })}{\text { Absorbansi blanko }} \times 100 \%$

Hasil perhitungan dimasukkan ke dalam persamaan regresi. Nilai $\mathrm{IC}_{50}$ diperoleh dari perhitungan pada saat persen inhibisi sebesar 50\%. 


\section{Uji total fenol (Socha, Juszczak, Pietrzyk dan Fortuna, 2009)}

Sebanyak $100 \mathrm{mg}$ sampel dalam $10 \mathrm{~mL}$ akuades. Kemudian dipipet sampel sebanyak $0,5 \mathrm{~mL}$ dan ditambahkan 0,3 $\mathrm{mL}$ reagen Folin-Cioucalteu, $2 \mathrm{~mL} \mathrm{Na}_{2} \mathrm{CO}_{3} 15 \%$ dan ditepatkan dengan akuades hingga volume larutan menjadi $5 \mathrm{~mL}$. Sampel divortex dan diinkubasi selama 2 jam. Sampel diukur dengan spektrofotometer UV-VIS pada panjang gelombang $750 \mathrm{~nm}$. Kurva standar asam galat dibuat dengan konsentrasi 10, 20, 40, 60, 80, 100 ppm. Kandungan total fenol dinyatakan sebagai jumlah ekuivalen $\mathrm{mg}$ asam galat (GAE) per gram sampel.

\section{Uji total flavonoid (Meda, Lamien, Romito, Millogo, dan Nacoulma, 2005)}

Sebanyak $100 \mathrm{mg}$ sampel dilarutkan dalam $10 \mathrm{~mL}$ methanol. Kemudian disaring dan diambil sebanyak $5 \mathrm{~mL} \mathrm{AlCl}{ }_{3} 2 \%$ (b/v). Sampel dihomogenkan dan diinkubasi selama 10 menit. Absorbansi diukur pada panjang gelombang 454,63 nm. Kuersetin sebagai standar dengan konsentrasi 10, 20, 30, 40, $50 \mathrm{ppm}$. Kandungan flavonoid dianggap sebagai jumlah ekuivalen mg kuersetin (QE) per gram sampel.

\section{HASIL DAN PEMBAHASAN}

\section{A. Flavonoid}

Komponen utama dari ekstrak kayu secang adalah brazilin. Brazilin termasuk golongan flavonoid. Menurut Kumar dan Pandey (2013) flavonoid terdiri dari kelompok besar senyawa polifenol memiliki struktur benzo- $\gamma$-pyrone dan terkandung pada berbagai jenis tumbuhan. Gugus fungsional hidroksil dalam flavonoid memberikan efek antioksidan yang dapat menangkap radikal bebas dan mengikat logam. Sejumlah penelitian menyatakan bahwa flavonoid memiliki efek protektif terhadap berbagai infeksi (penyakit yang disebabkan oleh bakteri dan virus) dan penyakit degeneratif seperti penyakit kardiovaskuler, kanker dan penyakit lain yang terkait dengan pertambahan usia. Kadar flavonoid dari ekstrak kayu secang yang diperoleh dari ekstraksi berbantuan ultrasonik dapat dilihat pada Tabel 1.

Tabel 1. Kadar Flavonoid (mg QE/g sampel) Ekstrak Kayu secang dengan menggunakan Pelarut, Suhu, dan Lama Ekstraksi Berbantuan Ultrasonik yang Berbeda

\begin{tabular}{|c|c|c|c|c|}
\hline \multirow{2}{*}{ Jenis Pelarut } & \multirow{2}{*}{ Suhu Ekstraksi } & \multicolumn{3}{|c|}{ Lama Ekstraksi } \\
\hline & & 20 menit & 30 menit & 40 menit \\
\hline \multirow[t]{3}{*}{ Air } & $20^{\circ} \mathrm{C}$ & $0,0353 \pm 0,0006$ & $0,0379 \pm 0,0107$ & $0,0322 \pm 0,0034$ \\
\hline & $30^{\circ} \mathrm{C}$ & $0,0384 \pm 0,0164$ & $0,0477 \pm 0,0003$ & $0,0392 \pm 0,0137$ \\
\hline & $40^{\circ} \mathrm{C}$ & $0,0359 \pm 0,0064$ & $0,0428 \pm 0,0060$ & $0,0406 \pm 0,0039$ \\
\hline \multirow[t]{3}{*}{ Etanol 65\% } & $20^{\circ} \mathrm{C}$ & $0,0666 \pm 0,0033$ & $0,0646 \pm 0,0086$ & $0,0773 \pm 0,0018$ \\
\hline & $30^{\circ} \mathrm{C}$ & $0,0566 \pm 0,0015$ & $0,0629 \pm 0,0110$ & $0,0667 \pm 0,0053$ \\
\hline & $40^{\circ} \mathrm{C}$ & $0,0681 \pm 0,0075$ & $0,0807 \pm 0,0039$ & $0,0723 \pm 0,0086$ \\
\hline
\end{tabular}

Pada Tabel 1 dapat dilihat bahwa kadar flavonoid dari ekstrak kayu secang berkisar $0,0322 \pm 0,0034-0,0807 \pm 0,0039 \mathrm{mg} \mathrm{QE} / \mathrm{g}$ sampel. Kadar flavonoid yang tertinggi diperoleh dari ekstraksi dengam menggunakan pelarut etanol $65 \%$ pada suhu $40^{\circ} \mathrm{C}$ selama 30 menit, sedangkan kadar flavonoid yang terendah diperoleh dari ektraksi dengan menggunakan pelarut air pada suhu $20^{\circ} \mathrm{C}$ selama 40 menit. Kadar flavonoid ekstrak kayu secang yang diektraksi sampai 30 menit terus mengalami peningkatan, setelah 30 menit kadar flavonoid cenderung mengalami penurunan. Hal ini disebabkan karena semakin lama terjadi kontak antara bahan ekstraksi dengan pelarut menyebabkan senyawa flavonoid pada bahan akan mengalami kerusakan sehingga kadar flavonoid pada ekstrak kayu secang akan semakin rendah.

Pada Tabel 1 juga dapat dilihat bahwa semakin tinggi suhu ekstraksi, maka kadar flavonoid ekstrak kayu secang cenderung semakin meningkat. Hal ini disebabkan karena suhu yang lebih tinggi akan memudahkan terlepasnya dinding sel bahan ekstraksi sehingga senyawa flavonoid lebih banyak terlarut di dalam pelarut. 
Pelarut etanol 65\% lebih banyak melarutkan senyawa flavonoid dibandingkan pelarut air. Senyawa flavonoid tergolong senyawa fenol yang sama-sama mempunyai gugus $\mathrm{OH}$ seperti halnya pelarut etanol $65 \%$ sehingga senyawa flavonoid dapat larut dengan baik di dalam etanol $65 \%$.

\section{B. Total Fenol}

Senyawa fenol merupakan komponen yang paling banyak yang dihasilkan dari metabolism sekunder tumbuhan. Beberapa peneliti menyatakan bahwa terdapat hubungan linier antara kandungan senyawa fenol dengan aktivitas antioksidan (Kozlowska, Scibisz, Zareba, dan Ziarno, 2015). Hasil analisis kadar total fenol dapat dilihat pada Tabel 2.

Tabel 2. Kadar Total Fenol (mg GAE/g sampel) Ekstrak Kayu secang dengan menggunakan Pelarut, Suhu, dan Lama Ekstraksi Berbantuan Ultrasonik yang Berbeda

\begin{tabular}{ccccc}
\hline \multirow{2}{*}{ Jenis Pelarut } & \multirow{2}{*}{ Suhu Ekstraksi } & \multicolumn{3}{c}{ Lama Ekstraksi } \\
\cline { 3 - 5 } & & 20 menit & 30 menit & \multicolumn{1}{c}{40 menit } \\
\hline Air & $20^{\circ} \mathrm{C}$ & $25,6250 \pm 5,8336$ & $23,4583 \pm 1,5910$ & $30,4167 \pm 4,7141$ \\
& $30^{\circ} \mathrm{C}$ & $26,9583 \pm 3,9480$ & $28,4167 \pm 2,8284$ & $30,9583 \pm 2,5338$ \\
\multirow{3}{*}{ Etanol $65 \%$} & $40^{\circ} \mathrm{C}$ & $28,1250 \pm 9,0156$ & $30,5833 \pm 4,5962$ & $32,8333 \pm 11,9029$ \\
& $20^{\circ} \mathrm{C}$ & $27,0833 \pm 3,5355$ & $25,6250 \pm 2,6516$ & $31,7917 \pm 2,5337$ \\
& $30^{\circ} \mathrm{C}$ & $37,7500 \pm 0,7071$ & $34,9583 \pm 6,1871$ & $38,7500 \pm 3,6534$ \\
& $40^{\circ} \mathrm{C}$ & $48,5417 \pm 7,1300$ & $47,2500 \pm 8,9567$ & $44,7083 \pm 2,2981$ \\
\hline
\end{tabular}

Pada Tabel 2 dapat dilihat bahwa kadar total fenol yang diperoleh berkisar 23,4583 $\pm 1,5910$ $48,5417 \pm 7,1300 \mathrm{mg}$ GAE/g sampel. Kadar total fenol yang paling tinggi dihasilkan dari ekstraksi dengan menggunakan pelarut etanol $65 \%$ pada suhu $40^{\circ} \mathrm{C}$ selama 20 menit dan yang paling rendah dihasilkan dari ekstraksi dengan menggunakan pelarut air pada suhu $20^{\circ} \mathrm{C}$ selama 30 menit. Semakin lama ekstrasi, maka total fenol akan semakin meningkat. Hal ini disebabkan karena semakin lama esktraksi maka semakin lama partikel bahan kontak dengan pelarut dan semakin banyak dinding sel bahan yang pecah akibat kavitasi ultrasonik sehingga semakin banyak senyawa fenol yang terlarut dalam pelarut. Namun kayu secang yang diekstraksi dengan pelarut etanol $65 \%$ selama lebih dari 20 menit mengalami penurunan kadar total fenol. Hal ini disebabkan karena semakin lama ekstraksi maka bahan ekstraksi semakin lama berkontak dengan panas yang dapat menyebabkan senyawa fenol akan terdegradasi dan kemudian mengalami reaksi polimerisasi yang merubah senyawa fenol menjadi senyawa tidak larut sehingga senyawa fenol yang terekstrak menjadi lebih rendah. Menurut Naczk and Shahidi, (2004); Chirinos, Rogez, Campos, Pedreschi, dan Larondelle , (2007), ekstraksi dengan waktu yang terlalu lama akan menyebabkan pemaparan lebih banyak oksigen dan cahaya (Hismath, Wan Aida, dan Ho, 2011), sehingga meningkatkan kemungkinan terjadinya oksidasi pada senyawa fenolik. Selanjutnya Tchabo, Ma, Kwaw, Xiao, Wu, dan Apaliya (2018) menyatakan bahwa waktu ekstraksi yang diperpanjang dapat meningkatkan kemungkinan oksidasi, epimerisasi dan degradasi senyawa bioaktif.

Pada Tabel 2 juga dapat dilihat bahwa semakin tinggi suhu ekstraksi, maka kadar total fenol semakin tinggi. Hal ini disebabkan karena semakin tinggi suhu maka dinding sel dari bahan ekstraksi menjadi semakin banyak yang terbuka sehingga semakin banyak senyawa fenol yang terlepas dan terlarut dalam pelarut. Al-Farsi dan Chang (2007) melaporkan bahwa semakin tinggi suhu maka kemampuan difusi dan kelarutan senyawa fenolik di dalam pelarut semakin meningkat. Selain itu, pelarut yang panas juga mampu melepaskan senyawa fenol dari dinding sel dan dapat memutus ikatan senyawa fenol dari konstituen sel (Wang et al, 2008) sehingga dapat meningkatkan kandungan senyawa fenol dalam ekstrak. Salinas, Jimenez, Torres, Agosin, dan Correa (2012) menyatakan bahwa suhu ekstraksi sampai $100^{\circ} \mathrm{C}$ cenderung menghasilkan senyawa polifenol dari ekstrak Thyme semakin meningkat. Quoc dan Muoi (2018) menyatakan bahwa suhu yang lebih tinggi dari suhu optimum ekstraksi menyebabkan senyawa fenol akan mengalami kerusakan.

Ekstraksi kayu secang dengan menggunakan pelarut etanol 65\% menghasilkan kadar total fenol yang lebih tinggi dibandingkan dengan menggunakan pelarut air. Hal ini disebabkan karena tingkat kepolaran senyawa fenol dengan pelarut etanol $65 \%$ adalah sama sehingga senyawa fenol dapat larut dengan baik di dalam pelarut etanol $65 \%$. Senyawa fenol dan pelarut etanol $65 \%$ 
tergolong dalam turunan alkohol yang mempunyai gugus $\mathrm{OH}$ yang dapat saling berikatan sehingga senyawa fenol lebih mudah larut di dalam etanol 65\%. Menurut Spigno, Marco, dan Tramelli (2007), konsentrasi fenol dari suatu ekstrak akan menurun jika bahan diekstraksi dengan pelarut etanol yang mengandung lebih dari 50\% air. Hal ini menunjukkan bahwa pelarut etanol merupakan pelarut yang baik untuk mengekstrak senyawa fenol. Selanjutnya Quoc dan Muoi (2018) menjelaskan bahwa penggunaan pelarut air destilasi pada ekstraksi menghasilkan rendemen senyawa fenol yang rendah dibandingkan dengan menggunakan pelarut etanol $60 \%$. Hal ini disebabkan aktivitas enzim polifenol oksidase dapat dihambat oleh pelarut organik (etanol 60\%) sedangkan di dalam pelarut air enzim tersebut berada dalam bentuk aktif yang dapat mendegradasi senyawa fenol. Penggunaan pelarut dengan tingkat kepolaran yang tinggi (misalnya air) dapat melarutkan senyawa-senyawa lain seperti gula, asam-asam organik dan protein larut air sehingga kadar senyawa fenol dalam suatu ekstrak menjadi rendah. Oleh karena itu proses ekstraksi dapat dilakukan dengan cara mengkombinasikan antara pelarut organik dengan pelarut air sehingga menghasilkan tingkat kepolaran pelarut yang moderat dan proses ekstraksi dapat berjalan dengan optimal.

\section{Antimikroba}

Staphylococcus aureus memiliki dinding sel yang terdiri dari lapisan peptidoglikan tanpa adanya tiga polimer pembungkus diluar sehingga selnya akan mudah terdenaturasi oleh senyawa aktif yang terdapat di dalam ekstrak kayu secang. Senyawa fenolik yang memiliki substansi cincin aromatic dengan satu atau lebih gugus hidroksil sehingga dapat menembus peptidoglikan. Akibatnya, dinding dan membran sel mengalami kerusakan dan mengganggu sistem transport aktif bakteri (Bachir dan Benali, 2012).

Tabel 3. Uji Antibakteri Staphylococcus aureus (mm) Ekstrak Kayu secang dengan menggunakan Pelarut, Suhu, dan Lama Ekstraksi Berbantuan Ultrasonik yang Berbeda

\begin{tabular}{ccrrc}
\hline \multirow{2}{*}{ Jenis Pelarut } & \multirow{2}{*}{ Suhu Ekstraksi } & \multicolumn{3}{c}{ Lama Ekstraksi } \\
\cline { 3 - 5 } & & 20 menit & 30 menit & 40 menit \\
\hline Air & $20^{\circ} \mathrm{C}$ & $12,30 \pm 0,7071$ & $11,65 \pm 0,9192$ & $12,55 \pm 1,3435$ \\
& $30^{\circ} \mathrm{C}$ & $13,00 \pm 1,4142$ & $12,35 \pm 1,9092$ & $16,50 \pm 1,1314$ \\
\multirow{3}{*}{ Etanol $65 \%$} & $40^{\circ} \mathrm{C}$ & $10,05 \pm 2,3335$ & $18,55 \pm 0,7778$ & $18,30 \pm 1,5556$ \\
& $20^{\circ} \mathrm{C}$ & $16,80 \pm 1,6971$ & $17,45 \pm 1,6264$ & $19,55 \pm 0,2121$ \\
& $30^{\circ} \mathrm{C}$ & $19,10 \pm 0,9900$ & $22,20 \pm 1,6971$ & $23,25 \pm 1,2021$ \\
& $40^{\circ} \mathrm{C}$ & $19,80 \pm 0,2828$ & $19,85 \pm 0,4950$ & $20,95 \pm 0,0707$ \\
\hline
\end{tabular}

Pada Tabel 3 dapat dilihat bahwa antibakteri ekstrak kayu secang berkisar antara $10,05 \pm 2,3335$ - 23,25 $\pm 1,2021 \mathrm{~mm}$. Antibakteri yang tertinggi terdapat pada ekstraksi dengan menggunakan etanol $65 \%$ pada suhu $30^{\circ} \mathrm{C}$ selama 40 menit, sedangkan antibakteri terendah dihasilkan dari ekstraksi dengan menggunakan pelarut air pada suhu $40^{\circ} \mathrm{C}$ selama 20 menit. Semakin lama proses ekstraksi, maka kemampuan antibakteri ekstrak kayu secang terhadap Staphylococcus aureus cenderung semakin meningkat. Hal ini disebabkan karena semakin lama proses ekstraksi maka semakin lama partikel-partikel bahan esktraksi berkontak dengan pelarut sehingga senyawa-senyawa antibakteri semakin banyak yang terlarut dalam pelarut.

Semakin tinggi suhu ekstraksi dengan menggunakan pelarut air maka kemampuan antibakteri ekstraks kayu secang cenderung semakin meningkat. Namun semakin tinggi suhu ekstraksi dengan menggunakan pelarut etanol $65 \%$, maka kemampuan antibakteri ekstrak kayu secang semakin menurun. Pada suhu ekstraksi $30^{\circ} \mathrm{C}$, pelarut etanol $65 \%$ dapat melarutkan senyawa-senyawa antibakteri dengan baik sehingga zona hambat dari ekstrak kayu secang semakin tinggi. Ekstraksi kayu secang dengan pelarut etanol $65 \%$ pada suhu yang melebihi $30^{\circ} \mathrm{C}$ menyebabkan senyawasenyawa antibakteri mengalami kerusakan sehingga zona hambat ekstrak kayu secang menjadi lebih rendah. Berdasarkan hasil penelitian diduga terdapat senyawa lain yang juga berperan sebagai antibakteri selain senyawa fenol dan flavonoid. Senyawa lain tersebut dapat diekstrak dengan baik menggunakan etanol $65 \%$, namun mudah rusak pada suhu ekstraksi yang melebihi suhu $30^{\circ} \mathrm{C}$.

Ekstraksi kayu secang dengan menggunakan pelarut etanol 65\% menghasilkan zona hambat ekstrak terhadap Staphylococcus aureus yang lebih tinggi dibandingkan dengan ekstraksi 
menggunakan pelarut air. Hal ini disebabkan karena senyawa-senyawa antibakteri dapat larut dengan baik di dalam pelarut etanol $65 \%$ dan pemisahan pelarut dengan ekstrak dapat dilakukan pada suhu yang lebih rendah.

\section{Aktivitas Antioksidan}

Berdasarkan hasil analisis menunjukkan bahwa semua sampel memiliki kemampuan penghambatan terhadap radikal DPPH yang tinggi. Hal ini ditunjukkan dari nilai $\mathrm{IC}_{50}$ kurang dari 50 ppm. Menurut Jun et al. (2003) cit Sumarlin, Suprayogi, Rahminiwati, Tjahja, dan, Sukandar (2015), aktivitas antioksidan digolongkan sangat aktif jika nilai $\mathrm{IC}_{50}$ kurang dari $50 \mathrm{ppm}$, digolongkan aktif bila nilai $\mathrm{IC}_{50}$ antara 50-100 ppm, digolongkan sedang bila nilai $\mathrm{IC}_{50}$ antara 101-250 ppm, dan digolongkan lemah bila nilai $\mathrm{IC}_{50}$ antara $250-500 \mathrm{ppm}$, serta digolongkan tidak aktif bila nilai $\mathrm{IC}_{50}$ lebih besar dari $500 \mathrm{ppm}$. Semakin kecil nilai $\mathrm{IC}_{50}$ berarti semakin tinggi aktivitas antioksidan. Aktivitas antioksidan $(\mathrm{mg} / \mathrm{mL})$ ekstrak kayu secang dengan menggunakan pelarut, suhu, dan lama ekstraksi berbantuan ultrasonik yang berbeda dapat dilihat pada Tabel 4.

Tabel 4. Aktivitas Antioksidan $\mathrm{IC}_{50}(\mathrm{mg} / \mathrm{mL})$ Ekstrak Kayu secang dengan menggunakan Pelarut, Suhu, dan Lama Ekstraksi Berbantuan Ultrasonik yang Berbeda

\begin{tabular}{|c|c|c|c|c|}
\hline \multirow{2}{*}{ Jenis Pelarut } & \multirow{2}{*}{ Suhu Ekstraksi } & \multicolumn{3}{|c|}{ Lama Ekstraksi } \\
\hline & & 20 menit & 30 menit & 40 menit \\
\hline \multirow[b]{4}{*}{ Etano1 650 } & $20^{\circ} \mathrm{C}$ & $4,2759 \pm 0,0017$ & $3,6880 \pm 0,0011$ & $3,4959 \pm 0,0132$ \\
\hline & $30^{\circ} \mathrm{C}$ & $4,0296 \pm 0,0254$ & $3,5336 \pm 0,0001$ & $3,3711 \pm 0,0508$ \\
\hline & $40^{\circ} \mathrm{C}$ & $3,3341 \pm 0,0776$ & $3,1747 \pm 0,0285$ & $2,7240 \pm 0,0211$ \\
\hline & $20^{\circ} \mathrm{C}$ & $2,3325 \pm 0,0039$ & $1,9641 \pm 0,0029$ & $1,4411 \pm 0,0016$ \\
\hline \multirow{2}{*}{ Etanol 65\% } & $30^{\circ} \mathrm{C}$ & $1,8171 \pm 0,0026$ & $1,6086 \pm 0,0052$ & $1,2978 \pm 0,0013$ \\
\hline & $40^{\circ} \mathrm{C}$ & $1,5393 \pm 0,0008$ & $1,2259 \pm 0,0020$ & $1,0577 \pm 0,0019$ \\
\hline
\end{tabular}

Pada Tabel 4 dapat dilihat bahwa aktivitas antioksidan $\mathrm{IC}_{50}$ ekstrak kayu secang berkisar antara $1,0577 \pm 0,0019-4,2759 \pm 0,0017 \mathrm{mg} / \mathrm{mL}$. Aktivitas antioksidan $\mathrm{IC}_{50}$ yang paling tinggi dihasilkan dari ekstraksi dengan menggunakan pelarut etanol $65 \%$ pada suhu $40^{\circ} \mathrm{C}$ selama 40 menit, sedangkan aktivitas antioksidan $\mathrm{IC}_{50}$ yang paling rendah dihasilkan dari ekstraksi dengan menggunakan pelarut air pada suhu $20^{\circ} \mathrm{C}$ selama 20 menit. Semakin lama waktu ekstraksi maka aktivitas antioksidan $\mathrm{IC}_{50}$ semakin meningkat. Hal ini disebabkan karena semakin lama waktu ekstraksi maka semakin lama kontak bahan ekstraksi dengan pelarut sehingga semakin banyak senyawa-senyawa antioksidan yang terekstrak. Menurut Sumarlin et al., (2015), keberadaan total fenolik, flavonoid dan vitamin C dapat mempengaruhi mekanisme radikal DPPH scavenging. Tingkat aktivitas antioksidan sangat dipengaruhi oleh kebedaraan senyawa-senyawa antioksidan seperti senyawa fenol dan flavonoid. Walaupun total fenol menurun pada lama ekstraksi melebihi 20 menit, namun senyawa flavonoid semakin meningkat pada proses ekstrasi melebihi 20 menit sehingga aktivitas antioksidan $\mathrm{IC}_{50}$ ekstrak kayu secang semakin tinggi. Menurut Sumarlin et al., (2015), flavonoid berpengaruh pada sifat antioksidan melalui aktivitas scavenging dan kelating. Selanjutnya van Acker et al., (1996) menjelaskan bahwa fenol dan senyawa polifenol, seperti flavonoid, banyak ditemukan pada produk makanan berasal dari tanaman, dan senyawa-senyawa tersebut telah terbukti memiliki aktivitas antioksidan yang signifikan

Tabel 4 juga menunjukkan bahwa semakin tinggi suhu ekstraksi maka aktivitas antioksidan $\mathrm{IC}_{50}$ ekstrak kayu secang semakin tinggi. Hal ini disebabkan karena pada suhu yang lebih tinggi dapat memudahkan pelepasan dinding sel dari bahan ekstraksi sehingga senyawa-senyawa antioksidan lebih banyak yang terlarut dalam pelarut.

Ekstraksi kayu secang dengan menggunakan pelarut etanol 65\% menghasilkan aktivitas antioksidan $\mathrm{IC}_{50}$ ekstrak kayu secang yang lebih tinggi dibandingkan dengan ekstraksi menggunakan pelarut air. Hal ini disebabkan karena senyawa-senyawa antioksidan dapat larut dengan baik di dalam pelarut etanol $65 \%$ dan pemisahan pelarut dengan ekstrak dapat dilakukan pada suhu yang lebih rendah sehingga dapat mencegah terjadinya kerusakan pada senyawa-senyawa antioksidan. Quoc dan Muoi (2018) menjelaskan bahwa penggunaan pelarut etanol 60\% dapat mengekstrak senyawasenyawa antioksidan yang lebih tinggi dibandingkan dengan menggunakan pelarut air. Sepahpour, 
Selamat, Manap, Khatib dan Razis (2018) menjelaskan bahwa pelarut organik lebih efektif mengekstrak senyawa polifenol dibandingkan pelarut air. Keberadaan senyawa polifenol sangat berkaitan dengan sifat-sifat antioksidan dari ekstrak.

\section{KESIMPULAN}

Hasil penelitian menunjukkan bahwa kondisi optimum ektraksi kayu secang dengan metode ultrasonikasi adalah menggunakan pelarut etanol $65 \%$ pada suhu $30^{\circ} \mathrm{C}$ selama 40 menit dengan parameter yaitu kadar flavonoid sebesar $0,0667 \pm 0,0053 \mathrm{mg}$ QE/g sampel, kadar total fenol sebesar $38,7500 \pm 3,6534 \mathrm{mg} \mathrm{GAE} / \mathrm{g}$ sampel, antibakteri Staphylococcus aureus sebesar 23,25 $\pm 1,2021 \mathrm{~mm}$, dan aktivitas antioksidan $\mathrm{IC}_{50}$ sebesar $1,2978 \pm 0,0013 \mathrm{mg} / \mathrm{mL}$.

\section{UCAPAN TERIMA KASIH}

Terima kasih disampaikan kepada Pengelola Program DIPA Penelitian Fakultas Teknologi Pertanian Universitas Andalas Padang yang telah membantu pendanaan penelitian ini.

\section{DAFTAR PUSTAKA}

Al-Farsi, M. A. and Chang, Y. L. 2007. Optimization of phenolics and dietary fibre extraction from date seeds. Food Chemistry 108(3): 977-985.

Bachir, G.R dan Benali, M. Antibacterial activity of the essential oils from the leaves of Eucalyptus globules against Eschericia coli and Staphylococcus aureus. Asian Pac J. Trop. Biomed 2: 739-742. DOI: 10.1016/S2 221-1691 (12)60220-2.

Chen, F., Zhang, Q., Liu, J., Gu, H., dan Yang, L. 2017. An Efficient Approach for the Extraction of Orientin and Vitexin from Trollius chinensis Flowers Using Ultrasonic Circulating Technique. Ultrasonic Sonochemistry 37 (2017) 267-278.

Chirinos, R., Rogez, H., Campos, D., Pedreschi, R. and Larondelle, Y. 2007. Optimization of extraction conditions of antioxidant phenolic compounds from mashua (Tropaeolum tuberosum Ruíz and Pavón) tubers. Separation and Purification Technology 55(2): 217225.

Deng, J., Xu, Z., Xiang, C., Liu, J., Zhou, L., Li, T., dan Yang, Z. 2017. Comparative Evaluation of maceration and Ultrasonic-Assisted Extraction of phenolic compounds from fresh olive. B gvfcUltrasonics Sonochemistry 37 (2017) 328-334.

Hismath, I., Wan Aida, W.M., dan Ho, C.W. 2011. Optimization of extraction conditions for phenolic compounds from neem (Aza-dirachta indica) leaves. Int. Food Res. J.,18: 931939.

Kumar, S., dan Pandey, A.K. 2013. Chemistry and Biological Activities of Flavonoids: An Overview. Hindawi Publishing Corporation, The Scientific World Journal, Volume 2013, Article ID 162750, 16 pages. http://dx.doi.org/10.1155/2013/162750.

Kozlowska, M., Scibisz, I., Zareba, D., dan Ziarno, M. 2015. Antioxidant properties and effect on lactic acid bacterial growth of spice extracts. CyTA - Journal of Food, 2015 Vol. 13, No. 4, 573-577, http://dx.doi.org/10.1080/19476337.2015.1022228.

Meda, A., Lamien, C.E., Romito, M., Millogo, J. dan Nacoulma, O.G. 2005. Determination of the total phenolic, flavonoid and proline contents in Burkina Fasan Honey, as well as their radical scavenging activity. Food Chem 91: 571-577.

Muharni, F. dan Farida, S. 2017. Uji Aktivitas Antibakteri Ekstrak Etanol Tanaman Obat Suku Musi di Kabupaten Musi Banyuasin, Sumatera Selatan. Jurnal Kefarmasian Indonesia. Vol.7 No.2-Agustus 2017:127-135, p-ISSN: 2085-675X, e-ISSN: 23548770. DOI: 10.22435/jki.v7i2.6070. 127-135. 
Nirmal N.P., Rajput, M.S., Prasad, R.G.S.V., Ahmad, M. 2015. Brazilin from Caesalpinia sappan heartwood and its pharmacological activities: A review. Asian Pacific Journal of Tropical Medicine 2015; 8(6): 421-430.

Puspaningrum, R. 2003. Pengaruh Ekstrak Kayu Secang (Caesalpinia sappan Linn) terhadap Proliferasi Sel Limfosit Limpa Tikus dan Sel Kanker K-562 (Chronic Myelogenous Leukemia) secara In Vitro. Skripsi. Fakultas Teknologi Pertanian Institut Pertanian.Bogor.

Quoc, L.P.T. dan Muoi, N.V. 2018. Ultrasound-Assisted Extraction Of Phenolic Compounds From Polygonum Multiflorum Thunb. Roots. Bulgarian Journal of Agricultural Science, 24 (No 2) 2018, 229-235.

Salinas, J.R.V., Jimenez, J.P., Torres, J.L., Agosin, E., dan Correa, J.R.P. 2012. Effects of Temperature and Time on Polyphenolic Content and Antioxidant Activity in the Pressurized Hot Water Extraction of Deodorized Thyme (Thymus vulgaris). J. Agric. Food Chem., 60 (44), pp 10920-10929.

Sepahpour, S., Selamat, J., Manap, M.Y.A., Khatib, A., dan Razis, A.F.A. 2018. Comparative Analysis of Chemical Composition, Antioxidant Activity and Quantitative Characterization of Some Phenolic compounds in Selected Herbs and Spices in Different Solvent Extraction Systems. Molecules 2018, 23, 402; doi:10.3390/molecules23020402, pp 1-17.

Singh, P., Singh, S., Kapoor, I.P.S., Singh, G., Isidorov, V., dan Szczepaniak, L. 2013. Chemical composition and antioxidant activities of essential oil and oleoresins from Curcuma zedoaria rhizomes, part-74. Food Biosci 3: 42-48.

Socha, R., Juszczak, L., Pietrzyk, S., dan Fortuna, T. 2009. Antioxidant activity and phenolic composition of herbhoneys. Food Chem 113:368-574.

Spigno, G., Marco, D.F.D., dan Tramelli, L. 2007. Effects of extraction time, temperature and solvent on concentration and antioxidant activity of grape marc phenolics. Journal of Food Engineering 81(1):200-208.

Sumarlin, L.O., Suprayogi, A., Rahminiwati, M., Tjahja, A., dan Sukandar, D. 2015. Bioaktivitas Ekstrak Metanol Daun Namnam serta Kombinasinya dengan Madu Trigona. J. Teknol. Dan Industri Pangan, Vol. 26(2): 144-145.

Tchabo, W., Ma, Y., Kwaw, E., Xiao, L., Wu, M., and Apaliya, M.T. 2018. Impact of extraction parameters and their optimization on the nutraceuticals and antioxidant properties of aqueous extract mulberry leaf. International Journal of Food Properties 2018, Vol. 21, NO. 1, 717-732 https://doi.org/10.1080/10942912.2018.1446025

Toegel, S., Wu, S.Q., Otero, M., Goldring, M.B., Leelapornpisid, P., Chiari, C. Caesalpinina sappan extract inhibits IL 1b-mediated overexpression of matrix Metalloproteinases in human chondrocytes. Genes Nutri 2012; 7(2): 312-318.

Van Acker, S.A.B.E., van Den Berg, D.J., Tromp, M.N.J.L., Griffioen, D.H., Van Bennekom, W.P., van der Vijgh, W.J.F., et al. 1996. Structural aspects of antioxidant activity of flavanoids. Free Radical Bio Med. 20 (3), 331-342. 